\title{
Explore the History of Humanity with the new ROAD Summary Data Sheet ${ }^{1}$ \\ Durch die Menschheitsgeschichte mit dem neuen ROAD Summary Data Sheet ${ }^{2}$
}

\author{
Michael Bolus ${ }^{a}$, Angela Bruch ${ }^{b}, M^{2}$ iriam Haidle ${ }^{b}$, Christine Hertler $^{b}$, Julia Heß ${ }^{b}$, Zara Kanaeva ${ }^{a}$, \\ Andrew Kandel ${ }^{a}$, Maria Malina ${ }^{a}$ and / und Christian Sommer ${ }^{a}$ \\ a Heidelberg Academy of Sciences and Humanities \\ Research Center "The Role of Culture in Early Expansions of Humans" (ROCEEH) \\ at the University of Tübingen \\ Rümelinstraße 23, 72070 Tübingen, Germany \\ michael.bolus@uni-tuebingen.de
}

b Heidelberg Academy of Sciences and Humanities

Research Center "The Role of Culture in Early Expansions of Humans" (ROCEEH)

Senckenberg Research Institute

Senckenberganlage 25, 60325 Frankfurt/M., Germany

miriam.haidle@senckenberg.de

The research center ROCEEH (The Role of Culture in Early Expansions of Humans) is a project of the Heidelberg Academy of Sciences and Humanities ${ }^{3}$ the aim of which is to discover, contextualize and preserve the deep past of humankind's cultural heritage. ROCEEH explores the history of humanity and its early expansions between three million and 20,000 years ago. ROCEEH also develops cultural concepts with which we examine how human culture evolved. ROCEEH makes the deep past of our cultural heritage accessible by compiling data

1 Bolus, M. et al. (2020). Explore the history of humanity with the new ROAD Summary Data Sheet. Archäologische Informationen 43, Early View, published online 7 Oct. 2020.

2 Bolus, M. et al. (2020). Durch die Menschheitsgeschichte mit dem neuen ROAD Summary Data Sheet. Archäologische Informationen 43, Early View, online publiziert 7. Okt. 2020.

3 The long-term project ROCEEH is located at the Senckenberg Research Institute in Frankfurt a. Main and the University of Tübingen. It has been promoted by the Joint Science Conference of the Federal Government and the governments of the states of the Federal Republic of Germany in the Academies' Programme. Funding is provided by the Federal Government of Germany (Federal Ministry of Education, Science and Research) and the states of Baden-Wurttemberg (Ministry of Science, Research and the Arts) and Hesse (Ministry of Science and the Arts).

(C) 2020 Kerns Verlag / mgfuopenaccess.org / https://doi.org/10.51315/mgfu.2020.29008

Cite this article: Bolus, M. et al. 2020. Explore the History of Humanity with the new ROAD Summary Data Sheet. MGfU 29: 145-147. 
about archaeological sites and their associated assemblages. With a new publication tool called the ROAD Summary Data Sheet this information is now available to the public in a concise format.

The ROCEEH Out of Africa Database (ROAD) archives systematically collected data from sites in Africa and Eurasia. The database contains a vast amount of archaeological, paleoanthropological, paleobiological, geographical and bibliographical information stored in more than 50 separate tables. Most of the data come from published scientific literature. As of October 2020, ROAD contains data from more than 1,900 localities, 12,000 assemblages and 3,400 publications, with data entry ongoing.

To make these data accessible to the scientific and general public, ROAD provides a tool for generating a data sheet summarizing information about each locality in the form of a PDF. The PDF presents essential data for a selected locality including its geographic coordinates, profiles of the geological and archaeological layers, and ages of the site, layers and assemblages. Furthermore, the PDF describes the various assemblages and their find types as well as publication sources. Each ROAD Summary Data Sheet is a publication in itself under the license CC BY-NC 4.0 and can be effectively used for science, education, data sharing and data control. With the publication of these data sheets, the project provides a public tool for exploring the early human past. The research center also hopes for further participation from external users to help keep the data as up-to-date and accurate as possible.

The ROAD Summary Data Sheets can be accessed without registration at: https://www.roceeh.uni-tuebingen.de/roadweb/.

If you are interested in learning more about the ROCEEH research center and possibilities for analyses with ROAD, please visit our homepage: www.roceeh.net. 
Die Forschungsstelle ROCEEH (The Role of Culture in Early Expansions of Humans) ist ein Projekt der Heidelberger Akademie der Wissenschaften ${ }^{4}$ mit dem Ziel, das frühe kulturelle Erbe der Menschheit zu erkunden, in einen Kontext zu stellen und zu bewahren. ROCEEH erforscht die Geschichte der Menschheit und ihrer frühen Ausbreitungen von drei Millionen bis 20.000 Jahren vor heute, indem kulturelle Konzepte zur Untersuchung der Entwicklung von menschlicher Kultur entwickelt und überprüft werden. Durch das Zusammenstellen der archäologischen Stätten und der mit ihnen verbundenen Informationen macht ROCEEH das früheste kulturelle Erbe zugänglich. Mit einem neuen Veröffentlichungswerkzeug namens ROAD Summary Data Sheet werden diese Informationen jetzt der Öffentlichkeit in zusammengefasster Form zur Verfügung gestellt.

Systematisch gesammelte Daten von Fundplätzen in Afrika und Eurasien werden in der ROCEEH Out of Africa Database (ROAD) archiviert. Diese enthält eine Vielzahl archäologischer, paläoanthropologischer, paläobiologischer, geografischer und bibliografischer Informationen, die in mehr als 50 separaten Tabellen gespeichert sind. Die meisten Daten stammen aus der veröffentlichten Fachliteratur. Mit Stand Oktober 2020 enthält ROAD Daten von mehr als 1900 Fundplätzen, 12.000 Inventaren und 3.400 Veröffentlichungen, wobei die Dateneingabe noch andauert.

Um diese Daten der Wissenschaft und der Öffentlichkeit zugänglich zu machen, bietet ROAD nun ein Werkzeug für die Generierung eines Datenblatts, in dem Informationen zu jedem Fundplatz in Form eines PDF zusammengefasst sind. Hier werden wichtige Daten für den jeweils ausgewählten Fundplatz angezeigt, einschließlich seines Standorts mit geografischen Koordinaten, Profilen der geologischen und archäologischen Schichten sowie dem Alter des Fundplatzes, der Schichten und der Inventare. Darüber hinaus werden Beschreibungen der einzelnen Inventare mit den unterschiedlichen Fundtypen und die Literaturquellen aufgeführt. Jedes ROAD Summary Data Sheet ist eine eigenständige, zitierfähige Veröffentlichung (unter der Lizenz CC BY-NC 4.0) und kann effizient für Wissenschaft, Bildung, Datenaustausch und Datenkontrolle verwendet werden. Mit der Publikation der Fundstellen-Datenblätter möchte die Forschungsstelle nicht nur ein öffentliches Werkzeug für die Erforschung der frühen Menschheitsgeschichte zur Verfügung stellen, sondern hofft auch auf Input von externen Benutzern, um so die ROAD-Datenbank auf dem neuesten Stand und so korrekt wie möglich zu halten.

Die ROAD Summary Data Sheets können ohne Registrierung unter folgender Adresse abgerufen werden: https://www.roceeh.uni-tuebingen.de/roadweb/.

Wenn Sie mehr über die ROCEEH-Forschungsstelle und weitere Analysemöglichkeiten mit der ROAD-Datenbank erfahren möchten, besuchen Sie bitte unsere Homepage: www.roceeh.net.

4 Das Projekt ROCEEH arbeitet am Senckenberg Forschungsinstitut in Frankfurt a. Main und der Universität Tübingen und wird gefördert im Akademienprogramm der Gemeinsamen Wissenschaftskonferenz der Bundesregierung und der Länderregierungen der Bundesrepublik Deutschland. Es wird finanziert durch Mittel der Bundesrepublik Deutschland (Bundesministerium für Bildung, Wissenschaft und Forschung) und der Länder Baden-Württemberg (Ministerium für Wissenschaft, Forschung und Kunst) und Hessen (Ministerium für Wissenschaft und Kunst). 